\title{
EFFECTS OF CYP2C19 AND P2Y12 GENE POLYMORPHISMS ON CLINICAL RESULTS OF PATIENTS USING CLOPIDOGREL AFTER ACUTE ISCHEMIC CEREBROVASCULAR DISEASE
}

\author{
Sen $\mathrm{HM}^{1, *}$, Silan $\mathrm{F}^{2}$, Silan $\mathrm{C}^{3}$, Degirmenci $\mathrm{Y}^{4}$, Ozisik Kamaran $\mathrm{HI}^{1}$
}

\begin{abstract}
*Corresponding Author: Halil Murat Sen, M.D., Department of Neurology, School of Medicine, Çanakkale Onsekiz Mart Üniversity, Barboros Mah., Terzioğlu Kampüsü, Tip Fakültesi, Çanakkale, Turkey. Tel : +90-286-218-37-38. Fax : +90-286-218-00-18. E-mail: hmuratsen@gmail.com
\end{abstract}

\begin{abstract}
The $C Y 2 C 19$ and $P 2 Y 12$ gene polymorphisms are responsible for resistance to clopidogrel, known as drug unresponsiveness. In this study we researched the effect of gene polymorphism on clinical results of patients who began clopidogrel therapy after acute ischemic cerebrovascular disease.

The study included 51 patients. The patient group included patients who had begun prophylactic clopidogrel due to acute ischemic cerebrovascular disease in the last 2 years. All patients were monitored by the Neurology Outpatient Clinic at Çanakkale Onsekiz Mart Üniversity Research Hospital, Çanakkale, Turkey, and only those monitored for at least 1 year were included in the study.

When the $* 1, * 2$ and $* 3$ alleles of the CYP2C19 gene polymorphism were evaluated, two patients were homozygotes for $* 2 / * 2,13$ patients were heterozygous for $* 1 / * 2$ and 36 patients were homozygotes for the wild type $* 1 / * 1$. No patient had the *3 allele. Three heterozygous patients, one for $* 2 / * 2$ and two for $* 1 / * 2$, stopped clopidogrel therapy due to repeated strokes and began taking warfarin. When
\end{abstract}

\footnotetext{
${ }^{1}$ Department of Neurology, School of Medicine, Çanakkale Onsekiz Mart Üniversity, Çanakkale, Turkey

${ }^{2}$ Department of Medical Genetics, School of Medicine, Çanakkale Onsekiz Mart Üniversity, Çanakkale, Turkey

${ }^{3}$ Department of Pharmacology, School of Medicine, Çanakkale Onsekiz Mart Üniversity, Çanakkale, Turkey

${ }^{4}$ Department of Neurology, School of Medicine, Düzce Üniversity, Düzce, Düzce, Turkey
}

evaluating P2Y12 $52(\mathrm{G}>\mathrm{T})$ and $34(\mathrm{C}>\mathrm{T})$ polymorphisms, all alleles were of the wild type.

The CYP2C19 and P2Y12 gene polymorphisms may cause recurring strokes linked to insufficient response to treatment of ischemic cerebrovascular disease. In our patient group, three patients suffered repeated strokes and these patients had the CYP2C19*2 gene polymorphism. As a result, before medication use, genetic testing is important for human life, quality of life and economic burden.

Keywords: Ischemic cerebrovascular disease (ICVD); clopidogrel; CYP2C19 and P2Y12 gene polymorphisms.

\section{INTRODUCTION}

Clopidogrel is used as a prophylactic monotherapy to prevent the development of a new attack of ischemic cerebrovascular disease (ICVD) [1]. Stroke is a major cause of disability and death, and affects nearly 16 million people globally each year [2]. As ICVD cause a high rate of morbidity and mortality, the importance of effective prophylactic treatment increases.

The clinical benefits of clopidogrel occur due to its inhibition of thrombocyte activation and aggregation $[3,4]$. Clopidogrel is actually a prodrug and transforms to active metabolite through CY2C19 enzyme in the cytochrome P450 (CYP450) enzyme family in the liver. As a result of CYP2C19 gene polymorphism, the transformation of clopidogrel to active metabolite reduces [5]. The CYP2C19*1 allele 
is a wild type allele linked to enzyme activity [6]. The most frequently seen variant causing reduced enzyme activity are the $C Y P 2 C 19 * 2$ allele and the less frequently seen $C Y P 2 C 19 * 3$ allele [7]. The $* 1 / * 1$ wild type produces normal metabolism, heterozygous $* 1 / * 2$ and $* 1 / * 3$ produce mild metabolic disorders and $* 2 / * 2, * 2 / * 3$ and $* 3 / * 3$ produce severe metabolic disorders [8]. P2Y12 receptors are found in the platelet membranes and play a role in adenosine diphosphate (ADP)-induced platelet aggregation [9]. The aim of the active clopidogrel metabolite is the ADP platelet receptor P2Y12, thus irreversibly inhibiting ADP linkage to platelets. As a result platelet activation and aggregation is inhibited [10,11]. The ADP-induced platelet aggregation varies between individuals [12]. The causes of these individual differences are genetic factors [13].

Patients with a P2Y12 gene polymorphism using clopidogrel with peripheral artery disease have been shown to develop more cerebral ischemic events than those without polymorphism [14]. Again, it has been reported that myocardial infarctus, stent thrombosis, and ischemic stroke development were higher in those with CYP2C19 gene polymorphisms compared to those without a polymorphism [15]. In acute coronary syndrome, stent patients with $P 2 Y 12$ and CYP2C19 single gene polymorphisms have been shown to have negative clinical results linked to unresponsiveness to clopidogrel; however, patients with a combination of both polymorphisms had worse clinical results [16]. In our study, we planned to research the clinical effects of CYP2C19 and P2Y12 gene polymorphisms in our ICVD patients who take clopidogrel.

\section{PATIENTS AND METHODS}

Patients. The patient group comprised of patients who began prophylactic clopidogrel $75 \mathrm{mg} /$ day as a result of acute ICVD in the previous 2 years. All patients were monitored by the Neurology Outpatient Clinic at Çanakkale Onsekiz Mart Üniversity Research Hospital, Çanakkale, Turkey. Those who had been monitored for at least 1 year were included in the study. Patients who stopped attending our clinic, or who did not take their medication regularly were not included in the study. The study was approved by the Institutional Review Board.

Detection of the CYP2C19 Genotype. Venous blood samples $(2 \mathrm{~mL})$ were collected from each patient in EDTA tubes. Genomic DNA was extracted from the whole blood using a high-pure template preparation kit (Roche Diagnostics $\mathrm{GmbH}$, Mannheim, Baden-Württenberg, Germany). $C Y$ $P 2 C 19$ alleles were detected by specific probes in Lightmix for the detection of human CYP2C19*1 (wild type allele), CYP2C19*2 (rs4244285) and CYP2C19*3 (rs4986893). Detection reagent (TIBMOLBIOL GmbH, Berlin, Germany) by real-time polymerase chain reaction (RT-PCR) (LightCycler 2.0; Roche Diagnostics $\mathrm{GmbH}$ ), according to the manufacturer's recommendations. The G681 A point mutation in exon 5 of $C Y P 2 C 19 * 2$ and G636A transition in exon 4 of $C Y P 2 C 19 * 3$ were detected. The genotypes were identified by running a melting curve analysis with specific melting points $(\mathrm{Tm})$. The wild type $C Y P 2 C 19^{*} 1$ exhibits a Tm $54.4{ }^{\circ} \mathrm{C}$ at channel 530 and $\mathrm{Tm} 53.4{ }^{\circ} \mathrm{C}$ at channel 640 . The allele variant $C Y P 2 C 19^{*} 2$ exhibits a $\mathrm{Tm}$ of $48.6^{\circ} \mathrm{C}$ at channel 530 and the allele variant $C Y P 2 C 19 * 3$ exhibits a Tm of $60.8^{\circ} \mathrm{C}$ at channel 640 .

Detection of the P2Y12 Genotype. The 52 $(\mathrm{G}>\mathrm{T})($ rs6809699) and $34(\mathrm{C}>\mathrm{T})($ rs 17602729) polymorphisms of the $P 2 Y 12$ gene was analyzed with the PCR-RFLP (restriction fragment length polymorphism) method. The primer sets used were: 5'-AAT AAT AAT TCA CCT CTG CGC CCG G3'/5'-CCG GAT TTG AAA GAA AAT CCT CA-3' for the $52(\mathrm{G}>\mathrm{T})$ polymorphism, and 5'-TTT AGA GGA GGC TGT GTC CAA-3'/5'-AAT AAT GTT ACCAGG CGC AGA GGT GAA-3' for the 34 (C>T) polymorphism. The PCR was performed with $25 \mu \mathrm{L}$ DreamTaq Green PCR master mix (Thermo Scientific, Pittsburgh, PA, USA) with $5 \mu \mathrm{L}$ (75 ng) DNA, $1 \mu \mathrm{m}$ of forward and reverse primers and PCR grade water in a total reaction volume of $50 \mu \mathrm{L}$. An ABI PRISM $^{\text {TM }} 9700$ thermal cycler (Applied Biosystems, Grand Island, NY, USA) was used for the PCR reactions. The thermal cycling conditions were: an initial denaturation step at $94^{\circ} \mathrm{C}$ for $3 \mathrm{~min}$. and 35 cycles at $94{ }^{\circ} \mathrm{C}$ for 20 seconds, $57^{\circ} \mathrm{C}$ for 20 seconds, and $72{ }^{\circ} \mathrm{C}$ for 25 seconds; a final extension was performed at 72 ${ }^{\circ} \mathrm{C}$ for 3 min. An SmaI enzyme (Thermo Scientific) was used for digestion of the amplification product for the detection of the $52(\mathrm{G}>\mathrm{T})$ polymorphism. The PCR product used to detect the $34(\mathrm{C}>\mathrm{T})$ polymorphism was digested with Tsp509 I (synonime TasI) (Thermo Scientific). The products were sizefractionated on a $2.0 \%$ agarose gel. 


\section{RESULTS}

The study included patients monitored for acute ICVD in the previous 2 years and monitored by our clinic for at least 1 year. All patients included in the study began clopidogrel after acute ICVD. A total of 51 patients [21 males $(41.17 \%)$ and 30 females $(58.83 \%)]$ were included. Their average age was 66.4 \pm 9.6 years.

When the $* 1, * 2$, and $* 3$ alleles of CYP2C19 were evaluated, two patients were homozygous for $* 2 / * 2,13$ patients were heterozygous for $* 1 / * 2$ and 36 patients were homozygous for the wild type *1/*1 alleles. No patient carried the $* 3$ allele. Three heterozygous patients, one for $* 2 / * 2$ and two for $* 1 / * 2$, stopped clopidogrel due to repeated strokes and began to take warfarin. These patients had no previous history of warfarin use.

When the patients' alleles were evaluated in the group without recurring ischemic stroke, the *2 allele frequency was $13.54 \%$. In the recurring ischemic stroke group, the $* 2$ allele frequency was $66.7 \%$. In the relative risk calculation of the recurring ischemic stroke group, the odds ratio (OR) was identified as 13.23 [95\% confidence interval $(95 \%$ CI) 6.45-27.11], which was significant at $p<0.0001$ (Table 1). When the P2Y12 $52(\mathrm{G}>\mathrm{T})$ and $34(\mathrm{C}>\mathrm{T})$ polymorphisms were evaluated, all alleles were of the wild type.

\section{DISCUSSION}

Clopidogrel is used to prevent the development of a new ischemic attack [1]. Clopidogrel prevents ICVD; it has also been shown to be effective in patients with peripheral artery disease who use clopidogrel $[14,17]$. However, after using the drug, individual differences in response were observed and this situation has brought insufficiency of clopidogrel treatment to the agenda $[18,19]$.

In our study, in spite of using clopidogrel, three of our 51 patients developed ICVD during at least
1 year of follow-up and these patients began taking warfarin instead. When these patients began clopidogrel treatment, they had no history of warfarin use. When the CYP2C19 gene was evaluated in our patients with recurring ICVD, one patient was homozygous for $* 2 / * 2$, and two were heterozygous for $* 1 / * 2$. In the patients with recurring ICVD, the $* 2$ allele frequency was significantly higher than in the group without recurring ischemia $(p<0.0001)$. In our three patients, recurring ICVD and subsequent necessity to change medication, was linked to the $C Y P 2 C 19$ gene polymorphism. This is because clopidogrel is a prodrug and transforms into its effective metabolite through the action of CYP2 C19 enzyme in the liver CYP450 enzyme family. The transformation of clopidogrel into active metabolite reduces when linked to CYP2C19 genetic variations [5].

The reasons for clopidogrel resistance are multifactorial and other reasons include medication interactions and insufficient use of the drug [20]. In medication interactions, proton pump inhibitors (PPI) attract attention because PPI, especially, are frequently prescribed with clopidogrel. Proton pump inhibitors use reduces the effects of clopidogrel on platelets. This situation is worrisome as it may cause recurring strokes [21]. In our patient group, there was no use of PPI by the patients who had recurring strokes. Similarly, patients who did not use the medication sufficiently, another cause of unresponsiveness to medication, were not included in the study.

Recently, there were increasing worries about the failure in effectiveness of clopidogrel, due to genetic variations in CYP2C19 in the CYP450 enzyme family that facilitates metabolism of the medication [20]. As a result, the American Food and Drug Administration recommended that though not required, testing should be carried out before use, due to possible low effectiveness [22]. In our patient group, none of the patients had any tests before beginning the drug as the current social security system in our country does not cover the cost of the tests. Together with covering the cost of the tests, it is estimated that about

Table 1. CYP2C19 allele frequencies and comparison in groups with recurring or non recurring ischemic cerebrovascular disease.

\begin{tabular}{|l|c|c|c|c|}
\hline Parameter & $* \mathbf{1}(\mathbf{\%})$ & $* \mathbf{2}(\mathbf{\%})$ & $* \mathbf{3}(\mathbf{\%})$ & OR, $\boldsymbol{p}$ Value \\
\hline Recurring ICVD [+] & $2(33.33)$ & $4(66.66)$ & - & $13.23,<0.0001$ \\
\hline Recurring ICVD [-] & $83(86.46)$ & $13(13.54)$ & - & $13.23,<0.0001$ \\
\hline
\end{tabular}


$3.0 \%(2.0-14.0 \%)$ of the population do not metabolize clopidogrel well [23].

Those with P2Y12 polymorphism using clopidogrel for peripheral artery disease are reported to have four times more ICVD than those with wild type genotypes. It has been shown that medications like aspirin are not affected by variations in P2Y12. These results may be linked to genetic variations in the target receptors for clopidogrel [14]. However, in our study, no patient was identified with the P2Y12 polymorphism.

In our patient group, no single person had both P2Y12 and CYP2C19 gene polymorphisms, so haplotype analysis was not possible. As a result, the clinical effects of such a combination could not be identified in our study. However, in a previous study of stent patients with acute coronary syndrome, the clinical results of clopidogrel treatment were monitored. It was shown that a combination of $P 2 Y 12$ and $C Y$ $P 2 C 19$ gene polymorphisms produced worse negative clinical results than each polymorphism alone [16]. The increase in the number of polymorphisms increasing the unresponsiveness to the drug was a sign that genetic variations are very important for clopidogrel effectiveness.

The CYP2C19 and P2Y12 gene polymorphisms may cause recurring stroke attacks linked to an insufficient response to ICVD treatment. Stroke is among the top causes of mortality and morbidity. Repeated ischemic stroke events increase this risk further. As a result, genetic testing before medication use is important for human life, standard of living and economic burden.

Declaration of Interest. The present study was supported by the Department of Scientific Research Projects Commission, Çanakkale Onsekiz Mart University, Çanakkale, Turkey. The authors report no conflicts of interest. The authors alone are responsible for the content and writing of this article.

\section{REFERENCES}

1. Adams RJ, Albers G, Alberts MJ, Benavente O, Furie K, Goldstein LB, et al.; American Heart Association; American Stroke Association. Update to the AHA/ ASA recommendations for the prevention of stroke in patients with stroke and transient ischemic attack. Stroke. 2008; 39(5): 1647-1652.
2. Mukherjee D, Patil CG. Epidemiology and the global burden of stroke. World Neurosurg. 2011; 76(6 Suppl): S85-S90.

3. Tousoulis D, Siasos G, Zaromitidou M, Oikonomou E, Maniatis K, Kioufis S, et al. The impact of CYP2C19 genotype on cardiovascular events and platelet reactivity in patients with coronary artery disease receiving clopidogrel. Int J Cardiol. 2013; 168(2): 1594-1596.

4. Heitzer T, Rudolph V, Schwedhelm E, Karstens M, Sydow K, Ortak M, et al. Clopidogrel improves systemic endothelial nitric oxide bioavailability in patients with coronary artery disease: evidence for antioxidant and antiinflammatory effects. Arterioscler Thromb Vasc Biol. 2006; 26(7): 1648-1652

5. Chae H, Kim M, Koh YS, Hwang BH, Kang MK, Kim Y, et al. Feasibility of a microarraybased point-of-care CYP2C19 genotyping test for predicting clopidogrel on-treatment platelet reactivity. Biomed Res Int. 2013; 2013: 154073. doi: 10.1155/2013/154073.

6. PharmGKB [Internet]. Palo Alto (CA): Stanford University. Gene: CYP2C19. Available from: http://www. pharmgkb.org/ gene/PA124. Accessed November 102014.

7. Scott SA, Sangkuhl K, Gardner EE, Stein CM. Clinical pharmacogenetics implementation consortium guidelines for cytochrome P450-2C19 (CYP2C19) genotype and clopidogrel therapy. Clin Parmacol Therapeut. 2011; 90(2): 328-332.

8. Kaikita K, Ono T, Iwashita S, Nakayama N, Sato $\mathrm{K}$, Horio E, et al. Impact of CYP2C19 polymorphism on platelet function tests and coagulation and inflammatory biomarkers in patients undergoing percutaneous coronary intervention. J Atheroscler Thromb. 2014; 21(1): 64-76.

9. Kim KA, Song WG, Lee HM, Joo HJ, Park JY. Effect of P2Y1 and P2Y12 genetic polymorphisms on the ADP-induced platelet aggregation in a Korean population. Thromb Res. 2013; 132(2): 221-226.

10. Savi P, Pereillo JM, Uzabiaga MF, Combalbert J, Picard C, Maffrand JP, et al. Identification and biological activity of the active metabolite of clopidogrel. Thromb Haemost. 2000; 84(5): 891-896. 
11. Savi P, Laplace MC, Maffrand JP, Herbert JM. Binding of $[3 \mathrm{H}]-2$ methylthio ADP to rat platelets - Effect of clopidogrel and ticlopidine. J Pharmacol Exp Ther. 1994; 269(2): 772-777.

12. Feng D, Lindpaintner $\mathrm{K}$, Larson $\mathrm{MG}$, Rao VS, O’Donnell CJ, Lipinska I, et al. Increased platelet aggregability associated with platelet GPIIIa P1A2 polymorphism: The Framingham Offspring Study. Arterioscler Thromb Vasc Biol. 1999; 19(4): 1142-1147.

13. Lordkipanidze M, Diodati JG, Palisaitis DA, Schampaert E, Turgeon J, Pharand C. Genetic determinants of response to aspirin: Appraisal of 4 candidate genes. Thromb Res. 2011; 128(1): 47-53

14. Ziegler S, Schillinger M, Funk M, Felber K, Exner M, Mlekusch W, et al. Association of a functional polymorphism in the clopidogrel target receptor gene, $\mathrm{P} 2 \mathrm{Y} 12$, and the risk for ischemic cerebrovascular events in patients with peripheral artery disease. Stroke. 2005; 36(7): 1394-1399.

15. Mao L, Jian C, Changzhi L, Dan H, Suihua H, Wenyi T, et al. Cytochrome CYP2C19 polymorphism and risk of adverse clinical events in clopidogrel-treated patients: A meta-analysis based on 23,035 subjects. Arch Cardiovasc Dis. 2013; 106(10): 517-527.

16. Tang XF, Zhang JH, Wang J, Han YL, Xu B, Qiao SB, et al. Effects of coexisting polymorphisms of CYP2 C19 and P2Y12 on clopidogrel responsiveness and clinical outcome in patients with acute coronary syndromes undergoing stent-based coronary intervention. Chin Med J (Engl). 2013; 126(6): 1069-1075.

17. CAPRIE Steering Committee. A randomized, blinded, trial of clopidogrel versus aspirin in patients at risk for ischemic events (CAPRIE). Lancet. 1996; 348 (9038): 1329-1339.

18. Gurbel PA, Bliden KP. Durability of platelet inhibition by clopidogrel. Am J Cardiol. 2003; 91(9): 1123-1125.

19. Gurbel PA, Bliden KP, Hiatt BL, O’Connor CM. Clopidogrel for coronary stenting: response variability, drug resistance, and the effect of pretreatment platelet reactivity. Circulation. 2003; 107(23): 2908-2913.

20. Spokoyny I, Barazangi N, Jaramillo V, Rose J, Chen C, Wong C, et al. Reduced clopidogrel metabolism in a multiethnic population: Prevalence and rates of recurrent cerebrovascular events. J Stroke Cerebrovasc Dis. 2014; 23(4): 694-698.

21. Anderson CD, Biffi A, Greenberg SM, Rosand J. Personalized approaches to clopidogrel therapy: Are we there yet? Stroke. 2010; 41(12): 2997-3002.

22. US Food and Drug Administration. Clopidogrel black box warning. Available from: http:// www.fda.gov/ drugs/drugsafety/postmarketdrugsafetyinformationforpatientsandproviders/ ucm203888.htm. Accessed November 10, 2014.

23. Terpening C. Clopidogrel: A pharmacogenomic perspective on its use in coronary artery disease. Clin Med Insights Cardiol. 2010; 4(1): 117-128. 